\title{
DEVELOPMENT STRATEGIES OF MICRO BUSINESS IN MAJALENGKA REGENCY
}

\author{
Ellen Rusliati \\ ellenrusliati@yahoo.co.id \\ Mulyaningrum \\ Mujibah A. Sufyani \\ Fakultas Ekonomi dan Bisnis Universitas Pasundan \\ Jl. Tamansari No. 6-8, Bandung Wetan 40116
}

received: 24/5/18; revised: 20/7/18; published: 31/12/18

\begin{abstract}
The purpose of this study was to determine the development strategies of micro business potential to utilize aerocity opportunities in Majalengka Regency. The local potential in Majalengka were agriculture and natural resource-based tourism. Processing of local raw materials into products that fit the needs of the community would be able to increase the income of the population. The research method used was descriptive qualitative. The results showed the right strategy was market penetration and new product development. Efforts to be taken to support the strategy included (1) Improving the quality of human resources in services and trade, (2) Innovation of new local based products, (3) Promotion of information technology utilization, (4) Increasing tourism infrastructure involving micro businessmen, (5) Business assistance, market survey, and management training involve Higher Education, (6) BUM Desa facilitations in machinery, storage, capital development, product marketing, (8) Producing products according to agricultural commodities.
\end{abstract}

Keywords: micro business; potencies; opportunities; Majalengka Regency

\section{INTRODUCTION}

Minister of Cooperatives and Small Medium Enterprises (SME), said that the number of entrepreneurs in Indonesia is about $1.65 \%$ of the population. Singapore $7 \%$, Malaysia 5\% and Thailand 4\% (Republika, $12 / 3 / 2015)$. If the number of entrepreneurs increases, it will also boost the economy of the country, with increasing employment, which will ultimately be able to improve the quality of community welfare. SMEs' are becoming increasingly important for the creation and development of a modern, dynamic and knowledgebased economy, because of their ability to be flexible and adapt quickly to a changing market, and to generate new jobs (Govori, 2013).

Developed countries have created their industrial power on the basis of SMEs, and this sector offers transitional countries the opportunity for the fastest implementation of modern solutions and practices (Džafić et al., 2011). A strong SME sector contributes highly to the economy, contributing to the gross domestic product, by reducing the level of unemployment, redusing in poverty levels and promotions of entrepreneurship activity (Sitharam and Hoque, 2016). If the efforts only focus on the cities, it will increase people's welfare, but uneven and gini ratio will not decrease from $41 \%$. Therefore, it is necessary to develop entrepreneurship in rural areas.

Majalengka is a regency in West Java whose geographical conditions are divided into 3 zones: (1) $40.03 \%$ mountains, (2) $31.27 \%$ corrugated/hilly, and (3) $28.70 \%$ lowlands of the total regency area. It also consists of 26 sub-districts and 330 villages. This condition allows the potential growth of local specific natural resources. As a lowland area supported by its strategic position, Majalengka Regency is very suitable to be developed into a business and industrial city, therefore the Government of West Java Province establishes Majalengka as a priority in infrastructure development that is Kertajati International Airport (Kab. Majalengka, 2018). With the concept of developing Kertajati as Aerocity, it will make Majalengka as a center for various supporting industries, as well as a center of economic growth in the eastern region of West Java Province.

In detail, the potential of Majalengka Regency has been determined by Peraturan Daerah No. 11 of 2011 on Spatial Planning in 2011 - 2031 as: (a) Cultivation areas consisting of production forests, agriculture, fisheries, mining, industry, tourism, settlements and other designations, (b) Center of urban and rural activities, (c) Strategic area of West Java and Regency. 
Majalengka Regency will become a very strategic area for new economic growth for the eastern region of West Java Province before the opening of Kertajati International Airport. Therefore, the people should prepare to deal with competitive market development situations, changes in livelihoods and culture. This should be prepared for them to anticipate for modernization. Micro businessmen need to be invited to innovate and pay attention to market demands, so that agricultural products can be absorbed by the market and provide added value.

Most of Majalengka Regency's people are farmers, so rural development remains a priority, including human resources and agribusiness-based economic development and agricultural technology implementation in order to increase production and productivity as an effort to strengthen food security and fulfillment of industrial raw materials.

The result of the preliminary observation revealed that the people of Majalengka Regency generally use agricultural products only for their own consumption and the rest are sold directly to the market. There is no crop processing process from local agricultural products, so the price falls on harvest time. As a result, even though farmers live well, they are not really better than before. From the preliminary data, it is found that the public interest for entrepreneurship is quite high, but it has not been supported by the application of appropriate technology and adequate management system, therefore the potential has not added significant value. Some communities have already processed their crops manually and very simply. As a result, the processed products of these agricultural products do not last long, and do not have high selling value. Their products are only sold in the local market, so the profit is not optimal. Eventually their entrepreneurial spirit is channeled to sell foreign products. Some people who have the potential to develop entrepreneurship even move to other cities, so the local potential left dormant and managed perfunctory.

Micro Enterprise is a productive business owned by individual and/or individual business entity with asset criteria of $\leq 50$ million rupiahs and turnover of $\leq 300$ million rupiahs, based on Law no. 20 year 2008 on Micro, Small, Medium Enterprise (www. bi.go.id). Micro enterprises are often confronted to functional management constraints. Cooperation between suppliers, entrepreneurs, and output markets is needed to ensure the availability of raw materials and markets. The ability of micro enterprises to produce local processed agricultural products that vary according to market demand will demand diversification and product differentiation. This research will be conducted in order to improve the competitiveness and the effectiveness of production and marketing for micro businesses in Majalengka Regency to improve welfare.
The low capability to diversify and differentiate local processed products according to market demand of the community in Majalengka Regency is caused by the lack of information about the development of needs of the current consumers, so the local farmers' products do not have the ability to compete. As a result, marketing activities become ineffective. Besides, it also requires a synergy between people in various matters related to product marketing management to increase sales. This research is expected to produce a micro business development strategy, so that the potential development of local agricultural products can be utilized more optimal, and well sold and effective in producing and marketing generate profits.

Specific objectives of the study consist of: (a) Identifying potential local agricultural products using Strengths, Weaknesses, Opportunities, Threats (SWOT) analysis to identify local potentials that can be developed to meet market needs, obtaining available opportunities, and building competitiveness and penetrating internal constraints and competition, (b) Analyzing functional management that includes production management, product marketing management, financial system, and human resource management.

From the background of the problem, we obtained information on the condition of the society and micro entrepreneurs in Majalengka Regency generally have the following characteristics: (1) Lack in product diversification and differentiation in accordance with market demand, (2) Lack in the possession of concept of integrated production strategy and tactics and market in order to have an advantage to compete, (3) Having a strong entrepreneurial spirit, but less developed optimally. To be a successful entrepreneur must be innovative applying advance technique to production and marketing. There is a strong connection between technological development and entrepreneurship. Technology makes entrepreneurship dynamic, it encourages diversifications and economies of scale (Okorie et al., 2014).

The process of formulating alternative strategies of Majalengka Regency development is done through a series of analysis that cover several stages beginning with descriptive analysis by identifying vision, mission and objectives. This identification is important to know further about the targets to be achieved. Internal analysis is done in the fields of management, marketing, finance, production/operation, human resources, and behavior change, while external analysis is done by considering Political, Economic, Socio-Cultural Demography, Technology factor.

The identification results will further be incorporated into the framework of strategy formulation consisting of (David and David, 2016 translated by Novita and Liza): (1) the input stage which is the stage of summarizing the basic information or input required in formulating the strategy. At this stage External Factors Evaluation (EFE) and Internal Factors Evaluation (IFE) matrix 
are generated. This analysis is conducted to identify various external-internal factors that have significant influence in achieving the predetermined objectives, (2) the matching stage, which is the focusing stage and generating the appropriate strategy alternatives company condition. At this stage, IE matrix is produced which is the result of internal-external environment analysis that provides an overview of the company's position, as well as strategies that must be implemented in maintaining its position. Then, the SWOT (Strengths Weaknesses Opportunities and Threats) matrix provides a combination of strategies that can be done based on identification of the threats and weaknesses, (3) Alternative micro-enterprise development strategy, which is a recommended strategy to be a strategy that can be a guide for Majalengka Regency.

(Alfaxard, 2013) stated that are some key factors are considered to be of great significance for integration of strategy formulation and implementation to occur. These factors are both internally and externally to the organization. Internal factors include organization structure, organization culture, leadership, company resources, strategies, rewards and staff motivation. External factors include economic and political, ecological, technology and globalization, and government regulations. External and internal factors have crucial impact to SMEs environment (Kraja and Elez, 2015). As the business environment frequently changes, a company should regularly analysis its internal and environments in order to further develop its business (Pakkanen, 2012).

Internal factor analysis include 7 factors (management, production and operation, behavior change, finance, human resources, management information system, and marketing) and external factors cover include 5 factors (economic, social culture, demography and environment, technology and competitive) qualitatively arranged in the form of internal and external factor matrix and SWOT matrix, which subsequently resulted in an alternative micro-enterprise development strategy.

The method of SWOT analysis is to take the information from environment analysis and separate it into internal (strengths and weaknesses) and internal issues (opportunities and threats). SWOT analysis indicates a framework to identify the strategies of achieving goals (Ommani, 2011). SWOT analysis will provide a good foundation for strategy, business proposition, the position and direction of company/organization, and even discover which ideas are worth pursuing (Fine, 2009). A clear strategy can help organization to increasing its efficiency in such competitive markets. Formulation the strategy is one of the most important process to keep the organization operates normally (Liao and Chen, 2009). Even though there are nine factors that affect strategy implementation to be successful and can be classified to 3 factors that is (1) mixed factors: strategy formulation and relationship among different units/departments and different strategy level; (2) hard factors: organizational structures and administrative systems; and (3) soft factors: implement tactics, executors, consensus, commitment and communication (Li et al., 2013).

An innovative and rational action means the ability of entrepreneur in positioning his business related to the influence of the internal environment as well as the influence of the external environment (Suhardiyah et al., 2017). Company size and resources affects the SME's in a way that enable them to work towards implementing; strategies, policies and standards which are acceptable in the particular industry (Malik and Chaudhary, 2010). Entrepreneurs must pay a proper attention to internal and external factors, keeping in mind their dynamism and variability, and adjust the practice accordingly (Dragnić, 2014). Internal and external factors influencing SMEs growth (Soini and Veseli, 2011). Principals' leadership styles had a positive influence on the preparation of strategic plan (Njoroge, 2013). The framework of this study can be seen in Figure 1.

\section{METHODS}

The method used in this research was descriptive qualitative by survey and observation in in Majalengka Regency. We could dissect, discuss, and recognize the problems, and got justification on the condition and practices that were in progress. In addition, evaluation and comparison of what people could do in handling similar situations or problems could also be used in future plans and decision-making. To apply survey research method in operational, hence it required a research design which is suitable to the condition of the depth the research was conducted. The research design focused on the micro-enterprise including the following processes: (a) Identification and diagnosis of research problems based on preliminary research results, (b) Determination of conceptual framework for research problems and relationships with previous researches, (c) Formulating research problems including making specifications of objectives, scope, (d) Developing a framework, (e) Selecting and defining variable measurements, (f) Preparing tools and techniques for data collection, (g) Performing editing and processing data, (h) ) Analyzing the data qualitatively, (i) Reporting of research results, including research process, discussion and interpretation of data, generalization, and suggest some suggestions and future research work.

\section{RESULTS}

Mountainous and hilly areas have abundant natural resource potential such as vegetables, fruits, food as well as tourism sector. The flat lowland areas were supported by strategic positions as the connecting areas of 4 districts: Sumedang, Indramayu, Cirebon and Kuningan, potentially developed into business and industrial zones, so it was natural that the West Java Provincial Government saw 
Majalengka as one of the priorities of infrastructure development to support the acceleration of development including the mega project of West Java International Airport development that will be built in Kertajati subdistrict, as well as centers for the relocation of various industries and its concept which was integrated with various facilities such as residential, university, hospital, shopping center, bussines center, resort, recreation.

Majalengka Regency GRDP (Gross Regional Domestic Product) contribution majorly from agriculture sector that reached $26,85 \%$ far above West Java. Table 1 is the contribution of Majalengka Regency GRDP compared to West Java Province in 2016. Contribution of the processing industry sector in Majalengka Regency is much lower than West Java Province.

Perda No. 11 Tahun 2011 on Majalengka Regional Spatial Plan 2011-2031 stated that this objective condition would encourage the development acceleration significantly, so Majalengka was demanded to develop, synchronize and synergize to the acceleration of development more comprehensively covering human resource development, infrastructure, economy based on agribusiness as well as small and medium industries and various other fields including the field of government for the creation of a good bureaucratic system, professional, clean and accountable. To improve public services based on minimum service standards as amission to achieve public trust, both government and society must walk hand in hand in order to actualize the vision of Religious, Advanced and Prosperous Majalengka Regency.

West Java International Airport and Kertajati Aerocity were built in Majalengka Regency in the north, precisely in Kertajati Sub District. The airport would be built in 5 villages namely, Kertajati Village, Kertasari Village, Bantarjati Village, Sukakerta Village, and Sukamulya Village. The construction of the two mega projects caused the demand for land for non-agricultural activities to increase. Based on the Regional Spatial Plan of Majalengka Regency, the land needed for the two mega projects was $5,000 \mathrm{Ha}$, for the airport 1,800 $\mathrm{Ha}$ and the aerocity 3,200 ha. Regional designation for the development was the airport and aerocity area in Kertajati sub-district, residential and service area in Jatitujuh Subdistrict, and for industrial area in Ligung Subdistrict. The region that experienced significant development was Jatitujuh Subdistrict with its development pattern following government policy that were area designation, distance, accessibility, and land use. Training for terracing system creation is needed for farmers to prevent the occurrence of landslides in hilly areas (Ayu Maimun, 2016).

\section{DISCUSSIONS}

The population of Majalengka Regency in 2015 based on Population Projection 2010-2020 was 1,182,019: 590,690 of them are male and the rest 591,419 are female. The number of open unemployed is $4.01 \%$ or 24,420 people (male 18,407 and female 5,883). Majalengka community, including the labor force and people who never had any education reaches $14.68 \%$, people whowere graduated from primary school are $44.96 \%$, graduated from junior high education $18.84 \%$, graduated from secondary education $15.32 \%$ and diploma and bachelor graduate $6.23 \%$ (Kab. Majalengka, 2018).

The main occupations of the population were agriculture, forestry, hunting, and fisheries. It reachess $28.69 \%$. Meanwhile, trade, retail, restaurant and hotel reaches $26.83 \%$ and processing industries reach $17.80 \%$. Majalengka community were majorly farmers, agricultural sector contribution to GRDP formation reaches $32.85 \%$ with economic value reaches Rp 353.7 billion. Agriculture in Majalengka was relatively fertile. The area of land used for rice fields is about $41.55 \%$ or 50,035 ha, using $72,10 \%$ irrigation and the rest of it is rainfed (Kab. Majalengka, 2018). Total productivity of rice in 2015 reached 664,993 tons, decreased $2.89 \%$ compared to 2014 , as a result of the decrease of planting area. Dry land of 70,389 Ha is used mostly for garden, state forest, and yard and building. The biggest total output of rice came from Kertajati and Ligung sub districts. Majalengka Regency had a very enchanting nature, as evidenced by various tourist attractions found with a very beautiful scenery. Most of the tourist attractions in Majalengka were still uncovered and rarely visited by tourists. Majalengka had at least 20 interesting natural tourist destinations.

Strategic position of Majalengka District is described as followed: (1) Based on National Spatial Plan (PP No. 26 tahun 2008), Majalengka Regency will be to build Kertajati Secondary Airport. The area around it will also be built Arjuna Sea Port. (2) In the spatial planning system of West Java Province, Majalengka is located between the Bandung National Activity Center and Cirebon National Activity Center with Kadipaten Regional Activity Center (Majalengka), as well as access to Indramayu Regional Activity Center and Tasikmalaya Regional Activity Center. Spatial Plan of West Java Province shows that Majalengka Regency has a strategic position which the arrangement is prioritized. (3) The strategic position of Majalengka Regency is supported by several strategic areas, such as follows: (a) The fast-growing area is the area along BandungCirebon corridor, Cikopo-Palimanan highway plan, Cisumdawu highway, and the area around Majalengka airport and the Kadipaten-Majalengka axis, (b) The potential growing areas are in the South: Majalengka Regency along the Lemahsugih - Bantarujeg - Talaga - Cikijing road corridor.

Majalengka Regency as an agrarian area had excellent land resources used for agriculture, plantation and forestry with several advantages, as well as other potential natural resources such as mining, water resources, beautiful natural resources that could be used for tourism, forest resources, oil and natural gas that can be utilized for the development of the regional economy. 
The population of Majalengka Regency was predicted to reach 1,182,019 (Kab. Majalengka, 2018) by 2015. The population, with the increasing quality of Human Resources, was a potential in the administration and development. Majority of the population of Majalengka Regency was Moslem. Maturity of religion understanding had encouraged people to implement religious values in all aspects of life and harmony of life. The relationship among other religions could also be well established.

Majalengka Regency had a repertoire and uniqueness in the diversity of cultural features. The cultural potential of Majalengka Regency is reflected in the public life order, art style, superior product creation, language and customs and values of mutual cooperation. If these potentiall of cultural diversity are wisely and democratically managed, they could be as the basic capital of development.

The formulation of strategy began with the analysis of internal and external factors to determine the potential and opportunities of Majelengka Regency with the establishment of International Airport of West Java. Analysis of external factors include (1) Economic, (2) Social, Cultural, Demographic, and Environment, (3) Politics, (2) Production and Operation, (3) Behavioral Changes, (4) Finance, (5) Human Resources, (6) Competitive, SIM, (7) Marketing. Based on the external factor matrix obtained, the total value was 2.77 and internal was 2.37. These can be seen in Figure 2 to determine the right strategy for micro business of Majalengka Regency.

Based on the external internal matrix, it appeared that Majalengka Regency is located in 5th Quadrant, through maintaining strategy. This result showed that micro entrepreneurs in general were only able to maintain their conventional business. Two strategies choosen were Market Penetration and Product Development (David and David, translated by Novita and Liza, 2016).

Ansoff Matrix was very useful for the formulation of marketing strategies, but must be preceded by SWOT analysis. The design included an integrated functional management (marketing, finance, production, and human resources) program, starting with market demand, product creation, source and use of funds, to human resources who understood business professionally. Based on the analysis of Figure 3, the alternative marketing strategy offered as a solution are; (1) market penetration, and (2) product development. Creativity of marketing program and entrepreneurial orientation with competitive environment factor had influences on marketing performance (Ismawanti, 2008).

The market penetration strategy was to seek a greater market share for current products in existing markets through better marketing efforts. This strategy had low risk. Approaches to market penetration strategies included: (1) maintaining / increasing market share, (2) dominating market growth, (3) eliminating competitors, (4) increasing customer use. (Wainaina and Oloko, 2016) argued that the penetration strategy had an effect on the company's growth.
Product development strategy was to strive for increased sales through current product improvements or new product development. This strategy had medium risk. This strategy required changes in business operations, including: (1) research and development, (2) customer needs assessment, (3) brand clarity. Customers generally want innovative products according to their needs. For micro and small business, success in developing new product innovations requires the intelligence of entrepreneurs in recognizing customers needs (Suendro, 2010).

The result of SWOT analysis performed shown in Figure 4 refers to SWOT Matrix. Based on the research and discussion that had been done, it can be obtained that opportunities owned by Majalengka Regency were (a) Increase in new employment, service and trade sector, (b) Ease of land, sea and air transportation, (c) Close to current tourist areas: Bandung and Cirebon, (d) Industry related to agriculture, (e) Increase in Majalengka Tourism and Culinary, (f) Untapped natural wealth, (g) Government Support through Majalengka Regulation no. 11 of 2011, (h) Information Technology Development, (i) Development of Production Technology. The threats faced by Majalengka Regency were: (a) Land usage transition, (b) Livelihood transition, (c) Cultural change, (d) Society's refusal, (e) Production Risks, (f) Market and Price Risks, (g) The entry of competitors who are more experienced in business.

The strengths of Majalengka Regency were (a) The introduction of local based products is started through OVOP (One Village One Product) and Village Owned Enterprise, (b) The diversity of products can be easily traced through the internet, (c) Cooperation with Companies, (d) Solidarity of local people, (e) The nature of kinship and the hospitality of the local people, (f) Manually prepared products have been produced, but not yet sold outside, (g) Local product sales booth already exist but not yet optimized, (h) The community is willing to innovate and change, (i) High motivation to try, (j) Utilization of adequate technology. The weaknesses of Majalengka Regency were (a) There is no business experience, (b) Production facilities are not available, (c) Difficulty of raw materials during seasonal transition, (d) Limited funds and ability to process, (e) Market is yet formed, (f) Product specifications required by the market, (g) Market segment that must be aimed, (h) Promotion program that must be done.

Better understanding for SMEs in addressing the local environment factors that significantly affects SMEs' performance. Studying the factors that affect SMEs performance is critical to understanding business continuity and growth and, hence, to supporting economic development within a region (Van Dut, 2015). Partner ideally need both breadth and significant expertise overlap to facilitate the shared language and vision necessary for productive collaborative learning interactions. Overlapping partner expertise when combined with a strong sense of personal trust, leads to elevated absorptive capacity, innovation and performance within entrepreneurial firms (Gemmel, 2013). 


\section{CONCLUSION}

Strategy that needs to be done based on SWOT analysis were (a) Increasing the quality of human resources in service and trade, (b) Development of new local based products, (c) Promotion, (d) Improvement of tourism infrastructure, (e) Business assistance, (f) Market survey, (g) License granting in accordance with Regional Spatial Plan, (h) Strengthening local culture. Based on external internal matrix, the chosen strategy was market penetration included (a) Maintaining/increasing market share, (b) Dominating market growth, (c) Eliminating competitors, (d) Increasing customer usage, and product development consisted of (1) Research and development, (2) Assessment of customer needs, (3) brand clarity.

\section{REFERENCES}

Alfaxard, K.G., 2013. Factors Influencing Strategy Implementation Among Flower Firms in Naivasha, Kenya.

Ayu Maimun. 2016. Majalengka Terpadu. ayumaimun. wagomu.id/e4540.html

David, Fred R. and Forest R. David. 2016. Manajemen Strategik, alih bahasa Novita Puspasari dan Liza Nurbani Puspitasari. Salemba Empat.

Dragnić, D., 2014. Impact Of Internal And External Factors On the Performance OfFast-Growing Small And Medium Business. Management 19, 119-160.

Džafić, Z., Sejfudin, Z., Okičić, J., Kožarić, A., 2011. Internal and External Obstacles to the Development of SMEs in Bosnia and Herzegovina. Communication 13, 143-171.

Fine, L.G., 2009. The SWOT Analysis: Using your strength to overcome Weaknesses. Using Opportunities to Overcome Threats, Createspace, US-SC-North Charleston.

Gemmell, R.M., 2013. Socio-cognitive foundations of entrepreneurial venturing (Doctoral dissertation, Case Western Reserve University).

Govori, A., 2013. Analysis of external factors affecting the development of SMEs in Kosovo.

Ismawanti, E., 2008. Analisis faktor-faktor yang mempengaruhi kinerja pemasaran dengan factor lingkungan sebagai variable moderat (Studi pada industri kerajinan batik di Pekalongan), eprints. undip.ac.id/17426/1/

Kab. Majalengka, B., 2018. Kabupaten Majalengka dalam Angka 44.

Kraja, Y.B. and Osmani, E., 2015. Importance of external and internal environment in creation of competitive advantage to SMEs.(Case of SMEs, in the Northern Region of Albania). European Scientific Journal, ESJ, 11(13).

Li, Y., Eppler, M.J., Sun, G., 2013. Making Strategy Work: A Literature Review on the Factors
Influencing Strategy Implementation, Handbook of Research on Strategy Process.

Liao, Z., Chen, Z., 2009. The connection Between External Environment and Internal Strategy (A Case Study of Scandinavian Airlines System. www.hig. diva-portal.org.

Malik, N.H., chaudhary, M.H., 2010. Factors Effecting Small and Medium Enterprises, Selection of Market Entry Mode (Dissertation).

Njoroge, R.W., 2013. Factors Influencing Preparation of Strategic Plan in Secondary Schools in Kikuyu District, Kenya. www.eap.uonbi.ac.ke

Okorie, N.N., Kwa, D.Y., Olusunle, S.O.O., Akinyanmi, A.O., Momoh, I.M., 2014. Technopreneurship: an urgent need in the material world for sustainability in Nigeria.(Report). Eur. Sci. J. 10, 59.

Ommani, A.R., 2011. Strengths, weaknesses, opportunities and threats (SWOT) analysis for farming system businesses management: Case of wheat farmers of Shadervan District, Shoushtar Township, Iran. African journal of business management, 5(22), pp.9448-9454.

Pakkanen, T.-M., 2012.Internal and external analysis Case: Markkinointi Pakkaset Oy, Degree Thesis. International Business. www.theseus.fi.

Sitharam, S. and Hoque, M., 2016. Factors affecting the performance of small and medium enterprises in KwaZulu-Natal, South Africa. Problems and perspectives in Management, 14(2), pp.277-288.

Soini, E., Veseli, L., 2011.Factors Influencing SMES Growth in Kosovo. Bachelor's Thesis International Business Management.Turku University of Applied Sciences.

Suendro, G., 2010. Analisis Pengaruh Inovasi Produk Melalui Kinerja Pemasaran Untuk Mencapai Keunggulan Bersaing Berkelanjutan, Studi Pada Industri Kecil Dan Menengah Batik. https:// ejournal.undip.ac.id.

Suhardiyah, M., Subakir, S., Binawati, D.K., 2017. Business Environment-Based Sustainablity to the Acievemnt of Financial Performance of Small Medium Enterprises in the City of Surabaya. IOSR Journal of Economics and Finance (IOSR-JEF). Vol. 8, Isuue I Ver.II (Jan - Feb). PP 32 -41.

Van Dut, Vo. 2015. The Effect of Local Business Environments on SMEs'Performance: Empirical Evidence From The Mekong Delta. Asian Academy of Management Journal. Vol. 20, No. 1, 101-122.

Wainaina, N.G., Oloko, M., 2016. Market Penetration Strategies and Organizational Growth: A Case of Soft Drink Sector in Kenya. International Journal of Management and Commerce Innovations. Vol. 3 Issue 2, pp 219-227, October.

www.bi.go.id

www.bps.go.id. 2015. Data Pembangunan Kabupaten Majalengka. 
Table 1. Contribution of each sector to GRDP Majalengka Regency and West Java in 2016

\begin{tabular}{clcc}
\hline Category & \multicolumn{1}{c}{ Description } & Majalengka (\%) & West Java (\%) \\
\hline A & Agriculture, Forestry, Fishery & 26.85 & 8.90 \\
C & Processing Industry & 14.31 & 42.49 \\
F & Construction & 11.99 & 8.12 \\
G & Large and Retail Trading, Car and Motorcycle Reparation & 16.56 & 15.15 \\
H & Other Services & 2.54 & 1.95 \\
I & Provision of Accommodation and Dining & 3.12 & 2.60 \\
\hline
\end{tabular}

Source: Badan Pusat Statistik West Java and Majalengka

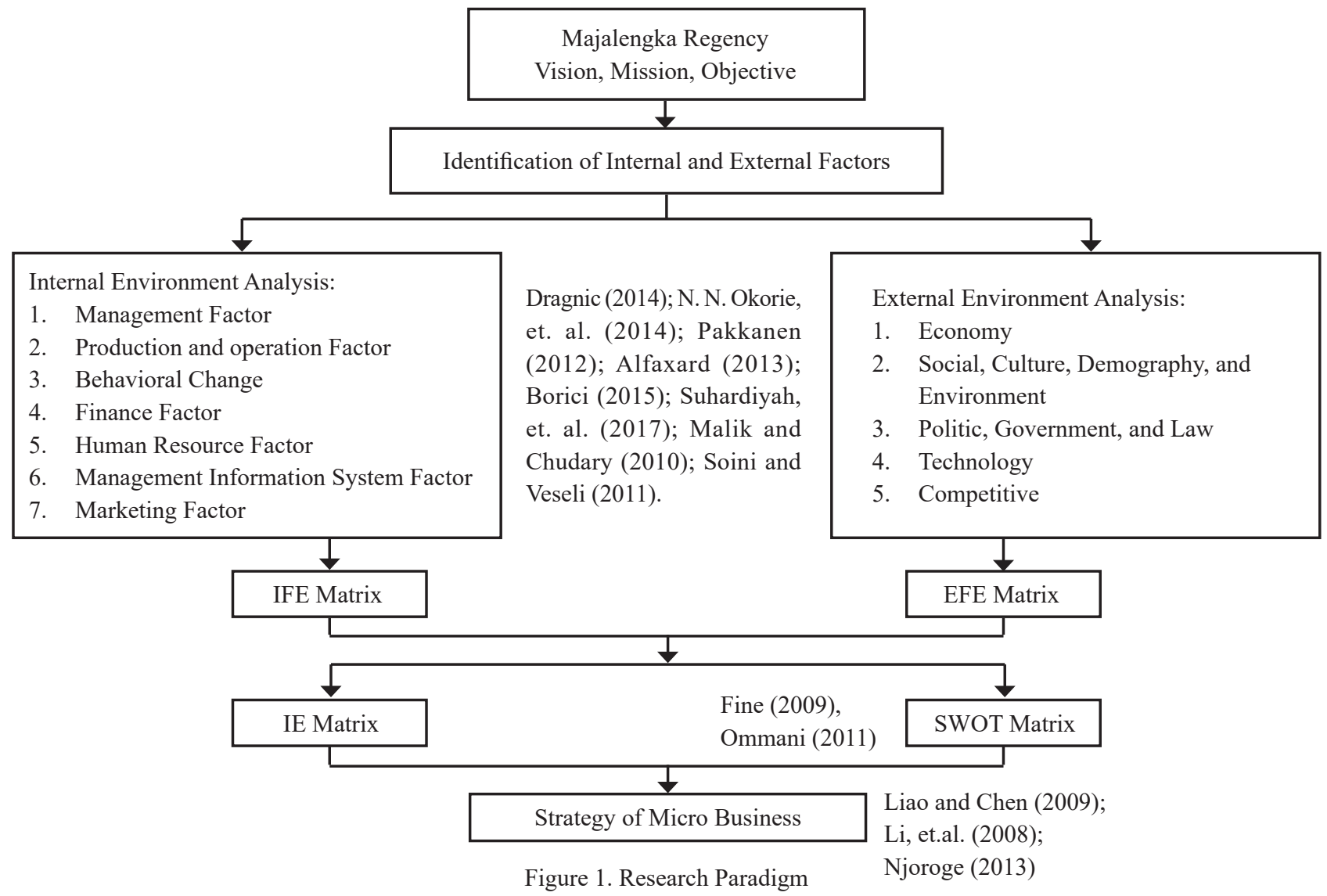

IFE SCORE

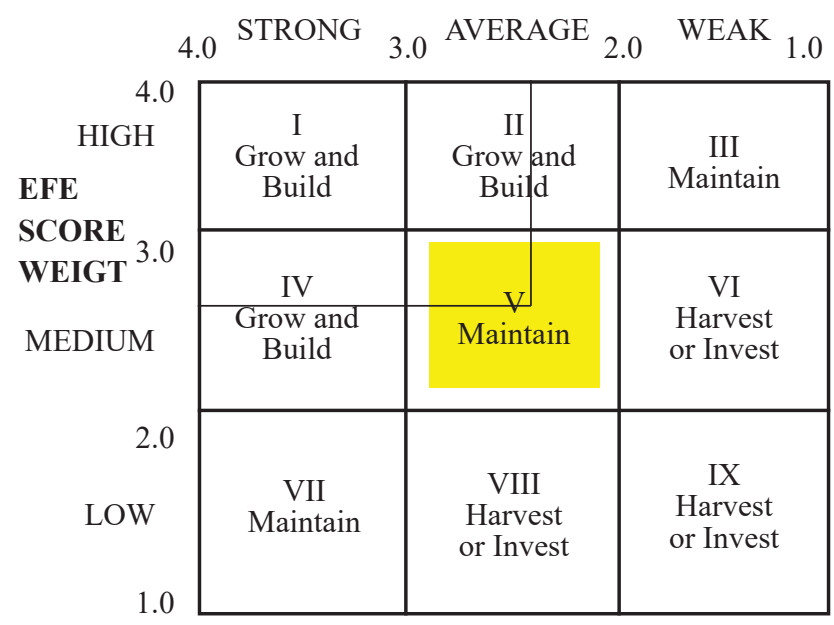

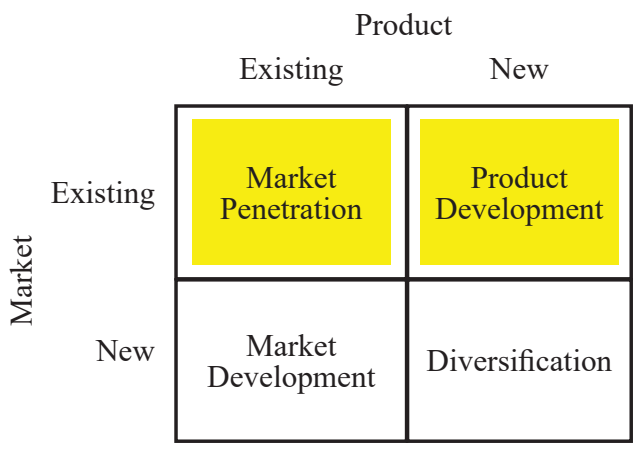

Sumber: Team FME. 2013

Figure 3. Marketing Alternative Strategy

Source: David and David, translated by Novita and Liza (2016)

Figure 2. Internal - External Matrix 


\begin{tabular}{|c|c|c|}
\hline & \begin{tabular}{|l} 
Strengths: \\
1. \\
The introduction of local based products \\
is started through OVOP (One Village \\
One Product) and Village Owned \\
Enterprise \\
2. The diversity of products can be traced \\
easily through the internet \\
3. Cooperation with Companies \\
4. Solidarity of local people \\
5. he nature of kinship and the hospitality \\
of the local people \\
6. Manually prepared products have been \\
produced, but not yet sold outside \\
7. Local product sales booth already exists \\
but not yet optimized \\
8. Willingness to innovate \\
9. Openness towards change \\
10. High motivation to try \\
11. Information technology access \\
12. Utilization of adequate information \\
technology for business
\end{tabular} & $\begin{array}{l}\text { Weaknesses: } \\
\text { 1. Business experience in continuing } \\
\text { previous business } \\
\text { 2. Production machine facility is not } \\
\text { available } \\
\text { 3. Difficulty of raw materials during } \\
\text { seasonal transition } \\
\text { 4. Hang on to predecessor practice } \\
\text { 5. The ability to manage finance } \\
\text { 6. Access on capital } \\
\text { 7. Low level of formal education } \\
\text { 8. Knowledge level on business } \\
\text { 9. Management } \\
\text { 10. Product specification required by the } \\
\text { market } \\
\text { 11. Aimed market segment must be clear, } \\
\text { 12. Put still around the local area }\end{array}$ \\
\hline $\begin{array}{l}\text { Opportunities: } \\
\text { 1. Increase in new employment, service } \\
\text { and trade sector } \\
\text { 2. Raw material transportation access } \\
\text { 3. Product transportation access } \\
\text { 4. Close to tourist areas: Bandung City and } \\
\text { Cirebon City } \\
\text { 5. Agriculture related industry } \\
\text { 6. Increase in Majalengka Tourism and } \\
\text { 7. Untapped natural wealth } \\
\text { 8. Government support through Majalengka } \\
\text { 9. Regulation no. } 11 \text { of } 2011 \\
\text { 10. Product Technology development }\end{array}$ & $\begin{array}{l}\text { STRATEGY S-O (using internal strengths } \\
\text { to attract advantages from external } \\
\text { opportunities): } \\
\text { 1. Increasing of the quality of human } \\
\text { resources in service and trade } \\
\text { 2. Development of New Local Based } \\
\text { Products } \\
\text { 3. Promotion } \\
\text { 4. Improvement of Tourism Infrastructure }\end{array}$ & $\begin{array}{l}\text { STRATEGY W-O (aimed to fix internal } \\
\text { weakness by taking advantages of } \\
\text { external opportunities): } \\
\text { 1. Business assistance } \\
\text { 2. Market survey } \\
\text { 3. Facilities from Village Owned } \\
\text { Enterprise for machinery, storage } \\
\text { facility } \\
\text { 4. Produce products according to season }\end{array}$ \\
\hline $\begin{array}{l}\text { Threats: } \\
\text { 1. There are still people who refuse } \\
\text { 2. Culture change } \\
\text { 3. Livelihood transition } \\
\text { 4. Land usage transition } \\
\text { 5. Production risk } \\
\text { 6. Market and Price risk } \\
\text { 7. The entry of more experienced } \\
\text { competitors in business }\end{array}$ & $\begin{array}{l}\text { STRATEGY S-T (using strengths to avoid } \\
\text { or lessen the effect of external threats): } \\
\text { 1. License granting in accordance with } \\
\text { Regional Spatial Plan } \\
\text { 2. Local culture strengthening }\end{array}$ & $\begin{array}{l}\text { STRATEGY W-T (is defensive tactic } \\
\text { which is directed to lessen internal } \\
\text { weaknesses and to avoid external } \\
\text { threats): } \\
\text { 1. Management, production process, } \\
\text { marketing and financial training }\end{array}$ \\
\hline
\end{tabular}

